\title{
The Effects of University Education on the Political Attitudes of Young Adults
}

\section{ERIC MINTZ}

Sir Wilfred Grenfell College

Memorial University of Newfoundland

\begin{abstract}
The attitudes of a panel of young adults in the Corner Brook, Newfoundland area on a variety of politically-relevant topics were examined over a two year period to measure the possible effects of a university education. Generally, those who attended university did not change significantly in their attitudes as compared to high school graduates who did not attend university.
\end{abstract}

\section{Résumé}

Les attitudes politiques d'un jury composé de jeunes de la région de Corner Brook à Terre-Neuve ont été étudiées pendant deux ans afin d'évaluer les effets possibles de la formation universitaire. De façon générale, les jeunes qui vont à l'Université ne modifient par leurs attitudes politiques si on les compare aux jeunes sortant du secondaire qui ne se sont pas inscrits à l'université.

The research reported in this article was funded by Challenge SEED grants and the Principal's Research Fund, Sir Wilfred Grenfell College. Research assistance was provided by Michael Walsh, Kevin Walker, Chris Clarke, and Mary Whelan. 


\section{Introduction}

A long-established finding of social science research is that the universityeducated are more liberal than those who have not attended university (Feldman \& Newcomb, 1970; Hyman \& Wright, 1979; Knoke \& Isaac, 1976; Niemi, Ross \& Alexander, 1978; Stouffer, 1955). In particular, studies have found that the university-educated tend to be more liberal in terms of greater tolerance, support for civil liberties, and openness to non-traditional social and moral views, rather than in terms of economic and social welfare views (Baer \& Lambert, 1990; Corbett, 1991). As well, those with a university education are more likely to be supportive of democratic values than the population as a whole (Lipset, 1960).

Cross-sectional analyses of the population showing that those who attended university tend to be more liberal in their political and social attitudes do not necessarily indicate that a university education has a socializing effect on students. University students are more likely to come from higher social class backgrounds and university graduates tend have higher income and higher occupational and social status than their age cohorts who did not attend university. As well, universities tend to attract persons with a different outlook than the population as a whole (Jennings \& Niemi, 1981). Not only may a university education be more attractive to the more intellectual and to those with greater cognitive abilities, but also there may be a greater interest in university education among those with a high level of concern about the world's problems. Universities may also disproportionately attract the ambitious who see a university education as the best route to individual success.

Studies examining the changes in the attitudes of students while attending university have generally found that there are substantial changes towards more liberal positions (Dressel \& Lehmann, 1965; Pascarella \& Terenzini, 1991). A few studies have provided evidence that these attitudinal changes are long-lasting (Newcomb, Koenig, Flacks \& Warwick, 1967; Weiner \& Eckland, 1979). Students taking social sciences courses have also been found to be more liberal than other students, although the Canadian evidence is mixed (Baer \& Lambert, 1990; Eitzen \& Brouillette, 1979; Feldman \& Newcomb, 1970; Guimond, Palmer \& Begin, 1989).

Overall, the evidence that a university education is responsible for socializing students into liberal values and attitudes is rather limited. In particular, few studies have compared those attending university to their 
cohorts who have different experiences as young adults (Ekehammar, Nilsson \& Sidanius, 1987).

The possible liberalizing effects of a university education have been attributed to the effects of exposure to diverse ideas which may foster tolerance of different perspectives and a reconsideration of conventional beliefs. As well, it could be argued that liberal values such as humanitarianism, equality, and freedom have been dominant in many North American universities and have influenced the attitudes and values of students.

The university-educated may also be more attuned to current trends in thought and more likely to adopt the values and attitudes held by various societal elites. Generally, this would result in more liberal attitudes on various social and political issues. If this explanation is valid, the strong revival of conservative views, such as the advocacy of competitive, market-oriented policies, might be expected to lead to a greater economic conservatism among those who have attended university in recent years.

The focus in many studies of the effects of a university education on political and social attitudes related to the "liberal"-"conservative" or "left"-"right" cleavage is too limited. There is evidence that, particularly among recent generations of young adults, the adoption of "postmaterialist" value priorities and the related "left-libertarian" attitudes associated with new social movements (such as the environmentalist and feminist movements) has created an important new and distinct political cleavage (often referred to as the "new politics" cleavage). Postmaterialist values and support for new social movements has been found to be particularly strong among university-educated young persons (Dalton, 1996; Inglehart, 1990). As well, there is some evidence that a university education has a stronger and more consistent effect in increasing support for feminist attitudes than in increasing support for standard liberal attitudes (Astin, 1993).

Although those with more education tend to have greater political interest, knowledge, efficacy, trust, and participation (Dalton, 1996), there is little research concerning whether a university education is directly related to the development of these general orientations to politics. 


\section{Hypotheses}

In accordance with previous research, it was hypothesized that those who attended university would become more liberal in their social and political attitudes than their peers who did not attend university. However, it was also hypothesized that the university-educated would become more conservative in their economic perspective in the sense of increasing support for competitive, market-oriented policies.

Based on research concerning the "new politics" cleavage, it was hypothesized that the university-educated would become more feminist, environmentalist, and postmaterialist in their attitudes and values.

Based on the assumption that a university education would tend to contribute to a general sense of self-confidence in understanding and acting in the world as well as increasing political awareness and knowledge, it was hypothesized that the university-educated would be more likely to develop a sense of political efficacy and political trust, more likely to develop an interest in politics including an interest in active participation in political life, and more likely to develop support for democratic procedures.

In addition to differences between those attending and not attending university, it was hypothesized that students taking social science courses would be more socially liberal, left-libertarian, and more participation-oriented than other university students. As well, based on some evidence that younger, more educated women are becoming more liberal than other gender and age groups (Bibby \& Posterski, 1992; Carroll, 1989; O'Neill, 1992), it was hypothesized that female university students would be more likely to move in liberal and left-libertarian directions than their male counterparts.

\section{Data and Methodology}

In the spring of 1990 questionnaires were administered in a class period to 251 Level III (grade 12) students at the two major high schools serving the Corner Brook, Newfoundland area.' Two years later, 124 of the young adults were successfully reinterviewed using an expanded version of the 1990 questionnaire. ${ }^{2}$ Thus, the first wave of the panel (1990) consists primarily of 17 and 18 year olds while the second wave (1992) consists of the same respondents mainly at 19 and 20 years old. In the 
analysis that follows, only those young persons who participated in both waves of the panel will be examined. ${ }^{3}$

By using a longitudinal panel design, changes among those attending university can be directly compared to changes among those not attending university controlling for prior differences in attitudes and social characteristics between the two groups.

To examine the liberalism of the young adults, indexes of support for civil liberties, toleration (in terms of acceptance of French language rights), and government provision of welfare were constructed (see Appendix). Economic conservatism was examined by creating an index of questions concerning attitudes related to competitiveness. To examine the "new politics" cleavage, indexes of environmentalist, feminist, and postmaterialist attitudes were developed. Orientations towards the political system were examined through indexes of political efficacy, political trust, democratic attitudes, and willingness to participate in political activities, along with a standard political interest question.

Some of the indexes (e.g., civil liberties, political efficacy and trust) were based on standard sets of questions. In other cases, indexes based on new questions were devised and pre-tested on a small number of university students.

Given the well-established finding that social class affects most socio-economic attitudes and evidence in some recent research that a "gender gap" exists on some issues among the young, multiple regression analyses were performed using class, gender, and education to examine changes in attitudes over the two year period.

\section{Findings}

In their initial attitudes (at the time of high school graduation), the university-bound did not differ significantly in their mean scores on most of the indexes (see Table 1). Significant differences between the two groups were found in terms of their orientations to the political system with the university-bound higher in political efficacy, political trust, and political interest.

Comparing attitudinal changes over a two year period, the hypothesis that those who attend university are more likely to move in a liberal direction was not strongly supported. Those attending university did become significantly more supportive of civil liberties, ${ }^{4}$ but changes in the direction of greater tolerance and greater support for social welfare 


\section{Table 1}

\section{Attitudes of 1990 and 1992 Panel Waves (mean index scores)}

\begin{tabular}{|c|c|c|}
\hline Indexes & non-university & university \\
\hline Civil Liberties (1990) & 8.7 & 9.2 \\
\hline Civil Liberties (1992) & 9.2 & $\underline{9.8}$ \\
\hline Tolerance (1990) & 10.6 & 11.4 \\
\hline Tolerance (1992) & 11.2 & 11.5 \\
\hline Welfare (1990) & 7.8 & 7.9 \\
\hline Welfare (1992) & 7.7 & 8.0 \\
\hline Competitiveness (1990) & 4.7 & 5.0 \\
\hline Competitiveness (1992) & $4.8 * *$ & $\underline{5.3} * *$ \\
\hline Feminism (1990) & 12.9 & 12.3 \\
\hline Feminism (1992) & $\overline{11.8}$ & 12.0 \\
\hline Environmentalism (1990) & 12.0 & 12.0 \\
\hline Environmentalism (1992) & 11.2 & 11.8 \\
\hline Postmaterialism (1990) & 6.5 & 6.5 \\
\hline Postmaterialism (1992) & 6.4 & 6.3 \\
\hline Efficacy (1990) & $8.9 * * *$ & $10.6^{* * *}$ \\
\hline Efficacy (1992) & $9.3 * *$ & $\underline{10.0} * *$ \\
\hline Trust (1990) & $8.5^{* *}$ & $9.5 * *$ \\
\hline Trust (1992) & 8.8 & 9.2 \\
\hline Participation (1990) & 9.4 & 9.0 \\
\hline Participation (1992) & 9.2 & 9.2 \\
\hline Democracy (1990) & $\underline{8.1}$ & 8.1 \\
\hline Democracy (1992) & 7.8 & 7.9 \\
\hline
\end{tabular}

Note: Indexes were created by adding scores on the questions listed in the Appendix (most of which were scored from 1 to 4: strongly disagree to strongly agree). Those answering "don't know" to any question were excluded from the calculation of the index. The potential range of environmentalism, feminism, efficacy, and tolerance indexes is 4 to 16 ; trust: 4 to 14 ; civil liberties: 4 to 13; participation: 6 to 12; postmaterialism: 4 to 8 ; welfare: 3 to 12 ; democracy: 3 to 9 ; and competitiveness: 3 to 6 .

\footnotetext{
* significant at .05

** significant at .01

*** significant at .001
}

Note: underlined 1990/1992 pairs had significant differences at least at .05 level using a two-tailed t-test. 
were not significant. Contrary to expectations, those not attending university significantly increased their tolerance over the two year period. Those who attended university became significantly more favourable to a competitive economy, while the change in attitudes towards competitiveness among the non-attenders was not significant.

In terms of the "new politics" cleavage, declines in feminist, environmentalist, and postmaterialist values and attitudes among those attending university were not significant. Among those not attending university, there was a significant decline in support for feminist and environmentalist positions.

In terms of orientations to the political system, political efficacy declined significantly among those attending university, while those not attending university became significantly less likely to adopt democratic attitudes. Political interest increased more among those not attending university (increasing from $39 \%$ to $51 \%$ expressing a "good deal" or "some" interest) than among those attending university (from $64 \%$ to $70 \%$ ).

Overall, two years after graduating from high school, those who attended university were significantly different than their peers only in terms of higher political efficacy, greater political interest and greater support for competitive economic policies (with greater support for civil liberties not quite reaching statistical significance). As well, those who attended university were less likely to support capital punishment and more likely to support abortion rights.

The hypothesis that those taking social science courses would be more likely to move in a liberal or left-libertarian direction was not supported (see Table 2). Those taking more than one social science course did significantly increase in their support for civil liberties, but this did not result in this group being more civil libertarian than those who did not take any social science courses. Those who did not take any social science courses declined significantly in support for feminist positions, but support for feminist positions was not higher among those taking more than one social science course.

Overall, those taking social science courses were, on the whole, not more liberal or left-libertarian prior to taking such courses, nor did taking social science courses have a clear effect in moving them in a particular ideological direction.

In analyzing the attitudes of high school graduates and their parents in 1990, one of the few strong generational differences was the tendency of young persons (particularly young women) to adopt more feminist 
Table 2

Attitudes by Number of Social Science Courses Taken, 1990 and 1992 (mean index scores)

\begin{tabular}{|c|c|c|c|}
\hline & none & one & more than one \\
\hline Civil Liberties (1990) & 9.7 & 8.6 & 9.2 \\
\hline Civil Liberties (1992) & 10.4 & 9.9 & 9.7 \\
\hline Tolerance (1990) & 12.4 & 11.1 & 10.7 \\
\hline Tolerance (1992) & 12.0 & 11.4 & 11.3 \\
\hline Welfare (1990) & 7.7 & 7.8 & 7.9 \\
\hline Welfare (1992) & 8.2 & 8.0 & 8.5 \\
\hline Competitiveness (1990) & 5.1 & 4.8 & 5.3 \\
\hline Competitiveness (1992) & 5.2 & $\underline{5.5}$ & 5.5 \\
\hline Feminism (1990) & $\underline{12.8}$ & 12.4 & 11.7 \\
\hline Feminism (1992) & $11.6^{*}$ & $12.8^{*}$ & $11.5^{*}$ \\
\hline Environmentalism (1990) & 12.8 & 11.8 & 11.4 \\
\hline Environmentalism (1992) & $12.6^{*}$ & $11.9^{*}$ & 11.2 \\
\hline Postmaterialism (1990) & 6.6 & 6.6 & 6.2 \\
\hline Postmaterialism (1992) & 6.6 & 6.4 & 6.0 \\
\hline Efficacy (1990) & 10.3 & 10.8 & 10.6 \\
\hline Efficacy (1992) & 9.5 & 10.7 & 9.9 \\
\hline Trust (1990) & 9.1 & 9.5 & 9.8 \\
\hline Trust (1992) & 9.2 & 9.3 & 9.0 \\
\hline Participation (1990) & 8.9 & 8.8 & 9.2 \\
\hline Participation (1992) & 8.7 & 9.8 & 9.3 \\
\hline Democracy (1990) & 7.8 & 8.2 & 8.1 \\
\hline Democracy (1992 & $7.4^{*}$ & $8.0^{*}$ & $8.0^{*}$ \\
\hline
\end{tabular}

Note: Indexes were created by adding scores on the questions listed in the Appendix (most of which were scored from 1 to 4 : strongly disagree to strongly agree). Those answering "don't know" to any question were excluded from the calculation of the index. The potential range of environmentalism, feminism, efficacy, and tolerance indexes is 4 to 16 ; trust: 4 to 14; civil liberties: 4 to 13; participation: 6 to 12; postmaterialism: 4 to 8 ; welfare: 3 to 12 ; democracy: 3 to 9 ; and competitiveness: 3 to 6 .

* significant at $.05 \quad * *$ significant at $.01 \quad * * *$ significant at .001

Note: underlined 1990/1992 pairs had significant differences at least at .05 level using a two-tailed t-test. 
positions than the parental generation (either mother or father). This created a larger "gender gap" among the younger generation than among the parental generation, particularly on questions concerning the position of women (Mintz, 1993). As well, young women were significantly more tolerant and less favourable to a competitive economy than young men. However, two years later, the "gender gap" between young women and men was not as pronounced, particularly as the tendency of young women to adopt feminist positions declined (data not shown). As well, there was a decline in the likelihood that young women would use the term "feminist" to describe their general beliefs (from 54\% to 33\%). ${ }^{5}$

The decline in feminist attitudes among young females was significant both for women who attended university and for those who did not attend university, but was more pronounced among the latter (see Table 3). Males who attended university increased their likelihood of adopting feminist positions. The decline in feminist position-taking among males not attending university was not significant.

Support for competitive economic policies increased significantly among women who attended university, erasing the difference from their male counterparts. The increase in support for competitive economic policies among women not attending university did not quite reach statistical significance.

\section{Multivariate Analyses}

The potential influence of attending university was also assessed by a multiple regression analysis (ordinary least squares). The regression equations treated each index value in 1992 as the product of the index value in 1990 plus class background (father's occupation dichotomized into working class and middle class), gender, and university education (dichotomized into attend/not attend). As was expected, index values in 1990 were almost always the best independent predictor (see Table 4). Class background made a significant contribution to three of the regression equations (with middle class backgrounds contributing to higher civil liberties, feminist, and efficacy scores). University education made a significant contribution to only one of the regression equations, moving students to a more favourable attitude towards a competitive economy. Gender did not make a significant contribution to any of the equations.

Running the same regressions substituting taking social science courses for attending university led to roughly similar results 
Table 3

Attitudes by Postsecondary Experience and Gender, 1990 and 1992 (mean index scores)

\begin{tabular}{|c|c|c|c|c|}
\hline & No uni & versity & Unive & ersity \\
\hline & Male & Female & Male & Female \\
\hline Civil Liberties (1990) & 8.5 & 8.9 & $\underline{9.2}$ & 9.3 \\
\hline Civil Liberties (1992) & 9.2 & 9.2 & $\underline{10.0}$ & 9.7 \\
\hline Tolerance (1990) & $9.6^{* * *}$ & $11.8 * * *$ & $10.2^{*}$ & $11.9 *$ \\
\hline Tolerance (1992) & $\underline{10.3} * * *$ & $12.2 * * *$ & 11.0 & 11.9 \\
\hline Welfare (1990) & 7.7 & 7.9 & 7.7 & 8.0 \\
\hline Welfare (1992) & 7.8 & 8.3 & 8.1 & 8.2 \\
\hline Competitiveness (1990) & 4.9 & 4.3 & $5.5^{*}$ & $4.6^{*}$ \\
\hline Competitiveness (1992) & 4.8 & 4.8 & 5.4 & $\underline{5.3}$ \\
\hline Feminism (1990) & $12.0^{* *}$ & $13.9 * *$ & $10.4^{* * *}$ & $13.3^{* * *}$ \\
\hline Feminism (1992) & 11.6 & $\underline{12.1}$ & $11.1 * * *$ & $\underline{12.6} * * *$ \\
\hline Environmentalism (1990) & 12.3 & 11.5 & 11.6 & 12.3 \\
\hline Environmentalism (1992) & 11.3 & 11.0 & 12.0 & 11.7 \\
\hline Postmaterialism (1990) & $6.2^{*}$ & $6.9^{*}$ & 6.4 & 6.6 \\
\hline Postmaterialism (1992) & 6.3 & 6.6 & 6.5 & 6.3 \\
\hline Efficacy (1990) & $8.3^{*}$ & $9.9^{*}$ & $11.3^{*}$ & $10.1 *$ \\
\hline Efficacy (1992) & $8.8 * *$ & $9.9 * *$ & $10.5 *$ & $9.6^{*}$ \\
\hline Trust (1990) & 8.4 & 8.7 & 9.9 & 9.3 \\
\hline Trust (1992) & 8.5 & 9.1 & 9.4 & 9.1 \\
\hline Participation (1990) & 9.6 & 9.2 & 8.9 & 9.1 \\
\hline Participation (1992) & 9.3 & 9.1 & 9.1 & 9.3 \\
\hline Democracy (1990) & $\underline{8.1}$ & 8.1 & 7.9 & 8.3 \\
\hline Democracy (1992) & $\underline{7.7}$ & 7.9 & 7.6 & 8.0 \\
\hline
\end{tabular}

Note: Indexes were created by adding scores on the questions listed in the Appendix (most of which were scored from 1 to 4 : strongly disagree to strongly agree). Those answering "don't know" to any question were excluded from the calculation of the index. The potential range of environmentalism, feminism, efficacy, and tolerance indexes is 4 to 16 ; trust: 4 to 14 ; civil liberties: 4 to 13; participation: 6 to 12 ; postmaterialism: 4 to 8 ; welfare: 3 to 12 ; democracy: 3 to 9 ; and competitiveness: 3 to 6 .

$*$ significant at $.05 \quad * *$ significant at $.01 \quad * * *$ significant at .001

Note: underlined 1990/1992 pairs had significant differences at least at .05 level using a two-tailed t-test. 
Table 4

Multiple Regression of 1992 Indexes by 1990 Attitudes, Class, Gender, and Postsecondary Experience

\begin{tabular}{|c|c|c|c|c|c|}
\hline Indexes (1992) & class & sex & university & $\begin{array}{c}\text { index } \\
1990\end{array}$ & $\begin{array}{c}\text { multiple } \\
\mathrm{R}\end{array}$ \\
\hline Civil Liberties & $\begin{array}{l}.27^{*} \\
(.12)\end{array}$ & $\begin{array}{l}-.14 \\
(.11)\end{array}$ & $\begin{array}{l}.01 \\
(.13)\end{array}$ & $\begin{array}{l}.51^{* * *} \\
(.11)\end{array}$ & $.63+++$ \\
\hline Tolerance & $\begin{array}{l}.07 \\
(.10)\end{array}$ & $\begin{array}{l}.14 \\
(.09)\end{array}$ & $\begin{array}{l}-.03 \\
(.10)\end{array}$ & $\begin{array}{l}.68^{* * *} \\
(.09)\end{array}$ & $.76+++$ \\
\hline Welfare & $\begin{array}{l}-.03 \\
(.13)\end{array}$ & $\begin{array}{c}.07 \\
(.11)\end{array}$ & $\begin{array}{c}.08 \\
(.13)\end{array}$ & $\begin{array}{l}.52^{* * *} \\
(.11)\end{array}$ & $.53+++$ \\
\hline Competitiveness & $\begin{array}{c}-.02 \\
(.15)\end{array}$ & $\begin{array}{c}.11 \\
(.13)\end{array}$ & $\begin{array}{l}.41^{* *} \\
(.16)\end{array}$ & $\begin{array}{r}.41^{*} \\
(.13)\end{array}$ & $.60+++$ \\
\hline Feminism & $\begin{array}{l}.28^{*} \\
(.12)\end{array}$ & $\begin{array}{l}.12 \\
(.14)\end{array}$ & $\begin{array}{l}-.01 \\
(.13)\end{array}$ & $\begin{array}{l}.44^{* *} \\
(.14)\end{array}$ & $.53+++$ \\
\hline Environmentalism & $\begin{array}{l}.13 \\
(.13)\end{array}$ & $\begin{array}{l}-.00 \\
(.00)\end{array}$ & $\begin{array}{l}.19 \\
(.14)\end{array}$ & $\begin{array}{l}.37^{* *} \\
(.12)\end{array}$ & $.46++$ \\
\hline Postmaterialism & $\begin{array}{l}.19 \\
(.15)\end{array}$ & $\begin{array}{l}-.11 \\
(.14)\end{array}$ & $\begin{array}{c}.07 \\
(.15)\end{array}$ & $\begin{array}{l}.29 * \\
(.13)\end{array}$ & .40 \\
\hline Efficacy & $\begin{array}{l}.33^{* *} \\
(.11)\end{array}$ & $\begin{array}{l}-.09 \\
(.10)\end{array}$ & $\begin{array}{l}-.06 \\
(.11)\end{array}$ & $\begin{array}{l}.52^{* *} \\
(.11)\end{array}$ & $.68+++$ \\
\hline Trust & $\begin{array}{l}.03 \\
(.15)\end{array}$ & $\begin{array}{l}-.05 \\
(.13)\end{array}$ & $\begin{array}{l}.02 \\
(.15)\end{array}$ & $\begin{array}{l}.52^{* * *} \\
(.13)\end{array}$ & $.54++$ \\
\hline Participation & $\begin{array}{c}-.07 \\
(.20)\end{array}$ & $\begin{array}{l}.05 \\
(.16)\end{array}$ & $\begin{array}{l}-.04 \\
(.20)\end{array}$ & $\begin{array}{l}.51^{* *} \\
(.16)\end{array}$ & .51 \\
\hline Demo & $\begin{array}{l}.17 \\
(.15)\end{array}$ & $\begin{array}{l}.17 \\
(.13)\end{array}$ & $\begin{array}{l}-.09 \\
(.15)\end{array}$ & $\begin{array}{l}.07 \\
(.13)\end{array}$ & .21 \\
\hline
\end{tabular}

Note: First entry is the standardized Beta. Bracketed entry is the standard error of Beta.

$*_{t}$-test significant at .05 level $* *_{t}$-test significant at .01 level $* * *_{t}$-test significant at .001 level. $+F$ ratio of equation significant at .05 level $++F$ ratio significant at .01 level $+++F$ ratio significant at .001 level. Class: father's occupation working class scored as 0 ; middle class scored as 1 . Sex: male scored as 0 ; female scored as 1 . University: did not attend scored as 0 ; attended scored as 1 . 
(see Table 5). Class background made a significant contribution to political efficacy and support for civil liberties (and close to significant for postmaterialism and feminism). Taking one or more social science courses was the strongest predictor of democratic attitudes, although that regression equation did not have a significant $F$ value. Again gender did not make a significant contribution to any of the equations (although close to significant for efficacy).

\section{Discussion}

It would be inappropriate to conclude definitively that a university education has little effect on political attitudes. Young adults educated in the Corner Brook area at the time of this study are not necessarily representative of young persons in other places ${ }^{6}$ or at other times. The analysis is based on small numbers thus making the finding of significant differences less likely to occur. Although a wide variety of questions were asked, there is the possibility that different questions would have revealed greater differences between the two groups.

Furthermore, it may be that two years of university education is insufficient to have a discernable effect on young adults: ${ }^{7}$ there might be a clearer effect with more years of education. As well, it is possible that there is a "sleeper" effect that develops over time. A university education might affect students' ways of thinking which might eventually lead to changes in specific attitudes. However, such an effect would be difficult to discern because, over time, the university educated may develop different attitudes as a result of their tendency to occupy higher status and higher paying jobs.

Finally, a university education may have effects that have not been measured in this study. Future researchers may want to examine whether a university education affects the nature of political discourse, the ways in which political issues are conceptualized, and the level of political sophistication.

The finding that those attending university became more favourable to a competitive economy does not necessarily contradict other studies that have found that a university education has a liberalizing effect. Those who attend university may have a tendency to become more liberal on social and moral issues while becoming more favourable to competition-oriented economic policies. 
Table 5

Multiple Regression of 1992 Indexes by 1990 Attitudes, Class, Gender, and Social Science Courses

\begin{tabular}{|c|c|c|c|c|c|}
\hline Indexes (1992) & class & sex & $\begin{array}{c}\text { social } \\
\text { science }\end{array}$ & $\begin{array}{c}\text { index } \\
1990\end{array}$ & $\begin{array}{c}\text { multiple } \\
\text { R }\end{array}$ \\
\hline Civil Liberties & $\begin{array}{l}.35^{*} \\
(.14)\end{array}$ & $\begin{array}{l}.01 \\
(.14)\end{array}$ & $\begin{array}{c}.03 \\
(.14)\end{array}$ & $\begin{array}{l}.56^{* * *} \\
(.14)\end{array}$ & $.67+++$ \\
\hline Tolerance & $\begin{array}{l}.05 \\
(.11)\end{array}$ & $\begin{array}{l}.08 \\
(.13)\end{array}$ & $\begin{array}{l}.06 \\
(.11)\end{array}$ & $\begin{array}{l}.71^{* * *} \\
(.13)\end{array}$ & $.73+++$ \\
\hline Welfare & $\begin{array}{l}.01 \\
(.13)\end{array}$ & $\begin{array}{l}-.09 \\
(.13)\end{array}$ & $\begin{array}{l}.20 \\
(.13)\end{array}$ & $\begin{array}{l}.55^{* * *} \\
(.13)\end{array}$ & $.61+++$ \\
\hline Competitiveness & $\begin{array}{c}.04 \\
(.19)\end{array}$ & $\begin{array}{c}.20 \\
(.20)\end{array}$ & $\begin{array}{c}.08 \\
(.19)\end{array}$ & $\begin{array}{l}.43^{* *} \\
(.19)\end{array}$ & .43 \\
\hline Feminism & $\begin{array}{c}.27^{*} \\
(.14)\end{array}$ & $\begin{array}{l}.01 \\
(.19)\end{array}$ & $\begin{array}{l}.13 \\
(.13)\end{array}$ & $\begin{array}{l}.58^{* *} \\
(.20)\end{array}$ & $.57+++$ \\
\hline Environmentalism & $\begin{array}{l}.19 \\
(.14)\end{array}$ & $\begin{array}{l}.00 \\
(.14)\end{array}$ & $\begin{array}{l}-.16 \\
(.14)\end{array}$ & $\begin{array}{l}.43^{* *} \\
(.15)\end{array}$ & $.57++$ \\
\hline Postmaterialism & $\begin{array}{l}.29 \\
(.16)\end{array}$ & $\begin{array}{l}.02 \\
(.15)\end{array}$ & $\begin{array}{l}-.14 \\
(.15)\end{array}$ & $\begin{array}{l}.31^{*} \\
(.15)\end{array}$ & $.50+$ \\
\hline Efficacy & $\begin{array}{l}.37^{* *} \\
(.14)\end{array}$ & $\begin{array}{l}-.25 \\
(.13)\end{array}$ & $\begin{array}{l}.17 \\
(.14)\end{array}$ & $\begin{array}{l}.34^{* *} \\
(.14)\end{array}$ & $.72+++$ \\
\hline Trust & $\begin{array}{l}-.01 \\
(.17)\end{array}$ & $\begin{array}{l}-.22 \\
(.17)\end{array}$ & $\begin{array}{l}.04 \\
(.17)\end{array}$ & $\begin{array}{l}.38^{*} \\
(.17)\end{array}$ & $.49++$ \\
\hline Participation & $\begin{array}{c}.05 \\
(.19)\end{array}$ & $\begin{array}{l}-.11 \\
(.18)\end{array}$ & $\begin{array}{c}.37 \\
(.20)\end{array}$ & $\begin{array}{l}.52 * * \\
(.18)\end{array}$ & $.61+$ \\
\hline Democracy & $\begin{array}{c}.02 \\
(.16)\end{array}$ & $\begin{array}{l}-.07 \\
(.16)\end{array}$ & $\begin{array}{c}.40^{*} \\
(.16)\end{array}$ & $\begin{array}{l}.12 \\
(.15)\end{array}$ & .42 \\
\hline
\end{tabular}

Note: First entry is the standardized Beta. Bracketed entry is the standard error of Beta.

$*_{t}$-test significant at .05 level $* * t$-test significant at .01 level $* * * t$-test significant at .001 level. $+\mathrm{F}$ ratio of equation significant at .05 level $++\mathrm{F}$ ratio significant at .01 level $+++F$ ratio significant at .001 level. Class: father's occupation working class scored as 0 ; middle class scored as 1 . Sex: male scored as 0 ; female scored as 1 . University: did not attend scored as 0 ; attended scored as 1 . Social Science: no courses scored as 0; one or more courses scored as 1 . 
Although this study did not find that the university-educated became more feminist or environmentalist, the decline in support for these attitudes among those not attending university suggests that attending university may have offset a decline in feminist and environmentalist attitudes that may have been occurring among the public in this time period.

The finding that, contrary to expectations, those attending university declined in political efficacy might indicate that a university education contributes to the development of a more realistic view of the world. Consistent with this explanation, the change among the university-educated primarily involved increased agreement with the statement that "generally, those elected to Parliament soon lose touch with the people", rather than involving changes on questions concerning citizen capabilities.

In addition to finding that attending university does not generally appear to have had a strong effect in changing political attitudes, this study has found that young persons with some university education do not generally differ significantly from those without a university education. It is possible that the very great increase in university participation rates has submerged the intellectual and social distinctiveness of the contemporary university-educated population. With about one-half of the high school graduates in the Corner Brook area continuing their education at the university level, it is clear that a university education is no longer an elite activity.

It is not clear why there was a decline in feminist position-taking over a two year period among women who attended and did not attend university. One possibility is that this reflects a general societal "backlash" against feminism. An alternative possibility is that pre-existing feminist attitudes were not reinforced by experiences subsequent to high school graduation. Only 14\% of female respondents in 1992 reported that they had personally experienced any discrimination in education or employment because of being a woman (with a similar proportion of male respondents reporting that they had been discriminated against because of being a man) ${ }^{8}$

Finally, the finding that those who took social science courses did not generally differ significantly from other university students could be viewed as consistent with studies that have found that taking high school civics courses has little effect on the attitudes of most students (Langton \& Jennings, 1968). Most students come to university with sets of attitudes already formed, and it may be that the professorate is neither as different nor as influential as we might like to think. 


\section{References}

Astin, A.W. (1993). What matters in college? Four critical years revisited. San Francisco, CA: Jossey-Bass.

Baer, D.E., \& Lambert, R.D. (1990). Socialization into dominant vs. counter ideology among university-educated Canadians. Canadian Review of Sociology and Anthropology, 24, 173-195.

Bibby, R.W., \& Posterski, D.C. (1992). Teen trends. A nation in motion. Toronto, ON: Stoddart.

Carroll, S.J. (1989). Gender politics and the socializing impact of the women's movement. In R.S. Sigel (Ed.), Political learning in adulthood (pp. 322-323). Chicago, IL: University of Chicago Press.

Corbett, M. (1991). American public opinion. Trends, processes, and patterns. White Plains, NY: Longman.

Dalton, R. (1996). Citizen politics in western democracies (second edition). Chatham, NJ: Chatham House.

Dressel, P.L., \& Lehmann, I.J. (1965). The impact of higher education on student attitudes, values, and critical thinking abilities. The Educational Record, 46, 248-258.

Eitzen, D.S., \& Brouillette, J.R. (1979). The politicization of college students. Adolescence, 14, 123-134.

Ekehammar, B., Nilsson, I., \& Sidanius, J. (1987). Education and ideology: Basic aspects of education related to adolescents' sociopolitical attitudes. Political Psychology, 8, 395-410.

Feldman, K.A., \& Newcomb, T.M. (1970). The impact of college on students. San Francisco, CA: Jossey-Bass.

Guimond, S., Palmer, D.L., \& Begin, G. (1989). Education, academic program and intergroup attitudes. Canadian Review of Sociology and Anthropology, 26, 193-216.

Hyman, H., \& Wright, C. (1979). Education's lasting effects on values. Chicago, IL: University of Chicago Press.

Inglehart, R.I. (1990). Culture shift in advanced industrial society. Princeton, NJ: Princeton University Press.

Jennings, M.K., \& Niemi, R.G. (1981). Generations and politics. A panel study of young adults and their parents. Princeton, NJ: Princeton University Press.

Knoke, D., \& Isaac, L. (1976). Quality of education and sociopolitical attitudes. Social Forces, 54, 524-529.

Langton, K.P., \& Jennings, M.K. (1968). Political socialization and the high school civics curriculum in the United States. American Political Science Review, 62, 852-867.

Lipset, S.M. (1960). Political man. Garden City, NY: Doubleday. 
Mintz, E. (1992). The attitudes of Newfoundland high school students: A comparison of two denominational schools. The Morning Watch, 20, 26-33.

Mintz, E. (1993). Two generations: The political attitudes of high school students and their parents. International Journal of Canadian Studies, special issue, 59-71.

Newcomb, T.M., Koenig, K.E., Flacks, R., \& Warwick, D.K. (1967). Persistence and change. Bennington College and its students after 25 years. New York, NY: John Wiley.

Niemi, R., Ross, R.D., \& Alexander, J. (1978). The similarity of political values of parents and college-age youths. Public Opinion Quarterly, 42, 503-520.

O'Neill, B. (1992). Gender gaps in opinion: The Canadian situation. Paper presented to the Annual General Meeting of the Canadian Political Science Association.

Pascarella, E.T., \& Terenzini, P.T. (1991). How college affects students. Findings and insights from twenty years of research. San Francisco, CA: Jossey-Bass

Stouffer, S. (1955). Communism, conformity, and civil liberties. New York, NY: Doubleday.

Weiner, T.S., \& Eckland, B.K. (1979). Education and political party. The effects of college or social class? American Journal of Sociology, 84, 911-928.

\section{Appendix}

\section{Survey Questions Used in Index Construction}

\section{Civil Liberties}

*1. The police should be able to wiretap the telephones of persons holding extremist ideas.

*2. Homosexual activity should be made illegal.

*3. Persons holding communist beliefs should not be permitted to teach in our schools.

4. Do you think that the use of marijuana should be legal or illegal?

\section{Tolerance}

1. All students across Canada should learn both English and French.

2. French-Canadian children should be able to receive an education in French anywhere in Canada if at all possible.

*3. The Canadian government should operate primarily in English.

4. Special efforts should be made to protect the French language in Canada.

\section{Welfare}

*1. Young persons who are able to work should not receive welfare payments from government. 
2. Governments should pay most of the costs of child care for working mothers.

*3. Unmarried women who have children should not receive welfare payments from government.

\section{Competitiveness}

1. Our economy should be made more efficient even if this means laying off some workers.

2. Do you think that government should try to assist businesses that are facing difficulties or do you think that government should not assist uncompetitive businesses?

3. Because of the problems in the Newfoundland fishery, do you think that the government should encourage fishermen to find other types of employment or do you think that the government should help fishermen to keep their jobs?

\section{Feminism}

1. Employers should be required to hire more women for good jobs.

*2. Women should be encouraged to stay at home to raise their children.

3. Universities should be required to reserve one-half of the places for women in programs such as engineering and science to ensure that there will be more women in such professions in the future.

*4. If a business has to lay off some workers, the first to be laid off should be women whose husbands have jobs.

\section{Environmentalism}

1. Offshore oil developments, such as Hibernia, should not proceed if there is a risk to the marine environment.

*2. Large economic projects that could create employment opportunities should be allowed to proceed even if they might endanger some rare plants or animals.

3. People should be encouraged to have fewer children so that there is room for all types of plant and animal life on earth.

*4. The paper mill in Corner Brook should not be forced to reduce its pollution because the mill is the backbone of this area's economy.

Postmaterialism (choice of second of each pair)

1. Over the next ten years, do you think that it is more important for our society to have a high rate of economic growth or to clean up our natural environment?

2. Over the next ten years, do you think that it is more important to ensure that order is maintained in our society or to encourage all people to have a say on controversial issues?

3. Over the next ten years, do you think that it is more important to create an economy that is internationally competitive or to ensure that all persons in our society are treated equally.

4. Over the next ten years, do you think that it is more important to fight crime or to develop our culture? 


\section{Efficacy}

*1. There's not much that ordinary citizens can do to affect what governments are doing.

*2. Generally, those elected to Parliament soon lose touch with the people.

*3. Sometimes politics and government seems so complicated that a person like me can't really understand what's going on.

*4. Governments don't seem to care what ordinary citizens think.

\section{Trust}

*1. Many people in government are dishonest.

2. Most of the people running government are smart people who usually know what they are doing.

3. Generally speaking, would you say that you have a great deal of confidence, some confidence, or almost no confidence in the ability of the Canadian government to do what's right?

4. Generally speaking, would you say that you have a great deal of confidence, some confidence, or almost no confidence in the ability of the Newfoundland government to do what's right?

\section{Participation}

Imagine that the Canadian government was doing something that you strongly disagreed with. Do you think that you would engage in any of the following activities?

1. Sign a petition

2. Call your Member of Parliament

3. Participate in a protest march

4. Organize others to vote against the government in the next election

5. Join with others in occupying government offices

6. Join with others in refusing to pay taxes

\section{Democracy}

*1. Governments should be able to make major decisions without having to have widespread public discussion of the issue.

2. All citizens should involve themselves in the discussion of political issues.

3. When developing its policies, do you think that governments should pay the most attention to the opinions of average citizens or to the opinions of experts?

Notes: Starred index items scored in reverse direction. Questions were not presented in this order in the questionnaire. 


\section{Notes}

1 Questionnaires were administered in all level III classes at Herdman Collegiate (Integrated Protestant) on May 15 and 16, $1990(\mathrm{~N}=162)$ and in four of the five Level III classes at Regina High School (Roman Catholic) on June 1 and June 4, $1990(\mathrm{~N}=89)$. According to the Principal of Regina, the five classes did not differ in their academic or social characteristics. Although Roman Catholic students are slightly underrepresented in this study, a comparison of students at the two schools found few differences in attitudes (Mintz, 1992). No attempts were made to administer questionnaires to students absent from class. Approximately $65 \%$ of all Level III students at the two schools filled out questionnaires. A telephone survey of their parents was also conducted using a similar questionnaire.

2 Interviews were conducted in June, July, and August 1992 through inperson, telephone or, in a few cases, mail questionnaires. Despite being conducted in the summer, the second panel wave may underrepresent those who left their home community for work or post-secondary education. The second wave slightly overrepresents females $(56.5 \%)$ as compared to the original wave $(50 \%)$. In terms of other social characteristics such as religion and parents' occupation, the second wave differed little from the first wave.

3 Seventy of the 124 young persons attended at least one semester of university. Those who attended university for less than two years differed very little from those who attended for two years and thus the two groups have been combined for the analyses that follow. Of the 54 panel members who did not attend university, 23 had attended a community college or vocational school, 35 had experienced regular employment, 2 were full-time home-makers, and 2 had experienced a substantial period of unemployment (with some having more than one significant post-secondary school experience). It should be noted that young adults who failed to complete high school are not included in this study.

4 Likewise, support for capital punishment decreased among those attending university from $30 \%$ to $15 \%$ while increasing slightly among those not attending university from $47 \%$ to $52 \%$. Support for a woman's right to choose an abortion increased from $51 \%$ to $66 \%$ among the university educated compared to an increase from $45 \%$ to $51 \%$ among those not attending university.

5 This was part of a series of questions asking respondents whether or not they would use various ideological terms to describe their general beliefs. Respondents were instructed that they could use more than one term.

6 Few differences were found between those who attended university in their hometown as compared to those who attended other universities. 
7 However, Dressel \& Lehmann (1965) found that the greatest effect of higher education was in the first two years of university.

8 This question was not asked in the 1990 wave. It is unlikely that lifecycle effects are responsible for the decline in feminist position-taking among women. Only $4 \%$ of the sample reported being married or living together in 1992 with the same proportion reporting having children. 